\title{
A Heminested Polymerase Chain Reaction for the Detection of Brazilian Rabies Isolates from Vampire Bats and Herbivores
}

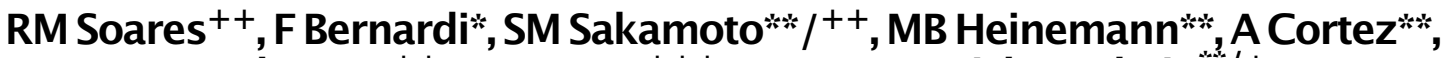

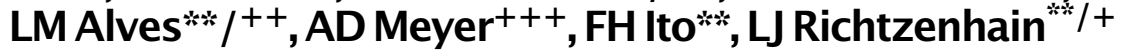

Instituto de Ciências Biomédicas, Universidade de São Paulo, São Paulo, SP, Brasil *Faculdade de Veterinária, Universidade Santo Amaro, São Paulo, SP, Brasil **Faculdade de Medicina Veterinária e Zootecnia, Universidade de São Paulo, Av. Prof. Dr. Orlando Marques de Paiva 87, Cidade Universitária, 05508-900 São Paulo, SP, Brasil

\begin{abstract}
A heminested-PCR (hn-PCR) using primers to the nucleoprotein-coding gene in a nested set was evaluated in the detection of Brazilian strains of rabies virus $(R V)$. A representative number of $R V$ nucleoprotein sequences belonging to genotype 1 were aligned. Based on such alignment, primers were directed to highly conserved regions. All 42 clinical samples positive by both fluorescent antibody and mouse inoculation tests were also positive by the hn-PCR. Brain tissue that had been left to decompose, obtained from an experimentally inoculated mouse was tested by hn$P C R$ and yielded positive results. In conclusion, primers designed here were capable of amplifying Brazilian RV isolates obtained from a rural epidemiological cycle.
\end{abstract}

Key words: rabies virus - polymerase chain reaction - detection of viral RNA - rabies diagnosis - Brazil

Rabies is a widespread zoonosis, which has been of great concern due to its ability to determine a fatal acute encephalomyelitis when the host is bitten by an ill animal (Wilkinson 1988). The causing agent is a virus that belongs to the Lyssavirus genus in the Rhabdoviridae family. Based on phylogenetic analyses of the nucleoproteincoding gene ( $\mathrm{N}$ gene), the Lyssavirus genus has been divided into seven genotypes. Genotype 1 includes rabies virus (RV) strains (Bourhy et al. 1993). RV genome is composed of a single-stranded, negative-sense, non-segmented RNA that codes for five separate proteins: nucleoprotein, glycoprotein, phosphoprotein, membrane protein and polymerase (Tordo 1991).

The World Health Organization (WHO) recommends that the fluorescent-antibody test (FAT) and mouse inoculation test (MIT) carried out simultaneously should be used for the detection of RV (Meslin et al. 1996). FAT is a rapid and low cost technique, which may show positive results, as it is able to detect viral antigens whether they are viable or not (Meslin et al. 1996). However, FAT's efficacy may be jeopardized when decomposed tissue is used. In such cases, PCR may be used as a surrogate due to its more appropriate performance (Sacramento et al. 1991, Kalmovarin et al. 1993, Whitby et al. 1997).

PCR based on $\mathrm{N}$ gene has been widely used for diagnostic purposes since it is one of the most conserved fractions in RV (Smith et al.1992, Kalmovarin et al. 1993, Heaton et al. 1997, Crepin et al. 1998, Heaton et al. 1999, Black et al. 2000).

The aim of this study was to design primers based on $\mathrm{RV}$ genotype $1 \mathrm{~N}$ gene and to evaluate the performance of

\footnotetext{
$\overline{{ }^{+} \text {Corresponding author. Fax: }}+55-11-3818-7928$. E-mail: leonardo@usp.br

${ }^{++}$Fapesp fellowship ${ }^{+++}$Capes fellowship

Received 6 March 2001

Accepted 26 September 2001
}

a hn-PCR for direct RV detection in clinical samples. Primers were based on the sequences of genotype 1 strains, including one Brazilian isolate (Kissi et al. 1995). Virus sequences were aligned by using the Clustal $\mathrm{X}$ computer program (Thompson et al. 1997) and the oligonucleotides were designed to recognize regions with high degree of similarity within the $\mathrm{N}$ genes. The segments that were selected for primer design are located in the middle of the $\mathrm{N}$ gene. Kissi et al. (1995) have demonstrated that such gene fraction shows a striking level of similarity among RV isolates. The physical and chemical properties of the primer were predicted by using the Oligo 4.0 computer program (Rychlik \& Rhoads 1989).

Primers with a maximum of three mismatches with any aforementioned sequence and no mismatch in the 3' terminal nucleotide were chosen. As the efficiency of PCR is inversely related to the length of the sequence, primers were chosen based on the shortest flanking distance. Primer sets P510/P784 and P510/P942 (P510:ATA GAG CAG ATT TTC GAG ACA GC; P784:CCT CAA AGT TCT TGT GGA AGA; P942:CCC ATA TAA CAT CCA ACA AAG TG) define 295 and 455 base pairs, respectively.

Samples were $20 \%$ (w/v) homogenate of brain material in PBS which had been stored at $-20^{\circ} \mathrm{C}$ and previously tested by FAT and MIT (FAT/MIT), as prescribed by the WHO (Meslin et al. 1996). These samples came from distinct geographical areas within the Brazilian territory and from multiple species of herbivores and vampire bats (Table). Total RNA was directly extracted from the samples by the TRIzol LS method, according to manufacturer's instructions (Gibco BRL). Reverse transcription was performed with $7 \mu \mathrm{l}$ of the extracted product added to a final volume of $20 \mu \mathrm{l}$ containing $1 \mathrm{mM}$ of each dNTP, 20 pmols of primer P510, 1 x RT buffer (Gibco BRL), 1 mM dTT, 200 units of M-MLV reverse transcriptase (Gibco, BRL) and $0.01 \%$ DEPEC treated ultra pure water. The mixture was incubated for $1 \mathrm{~h}$ at $42^{\circ} \mathrm{C}$.

A primary amplification was performed in $5 \mu \mathrm{l}$ of the reverse transcripted-cDNA template in a final volume of $50 \mu \mathrm{l}$, containing $0.2 \mathrm{mM}$ of each dNTP, 25 pmols of primer 
TABLE

Results of heminested-PCR (hnPcR) on fluorescent-antibody test/mouse inoculation test positive samples

\begin{tabular}{|c|c|c|c|}
\hline Sample $^{a}$ & Host & Locality $b$ & hnPCR \\
\hline 230/91 & Bovine & Ponta Porã/MS & + \\
\hline 264/91 & Bovine & Dourados/MS & + \\
\hline $697 / 91$ & Ovine & Goiânia/GO & + \\
\hline $06 / 94$ & Bovine & Ibiuna/SP & + \\
\hline $07 / 86$ & Bovine & Cajati/SP & + \\
\hline $07 / 91$ & Bovine & Apiaí/SP & + \\
\hline $12 / 83$ & Bovine & Aquidauana/MS & + \\
\hline $13 / 88$ & Bovine & Aguaí/SP & + \\
\hline $14 / 96$ & Bovine & Palmas/TO & + \\
\hline $15 / 94$ & Bovine & São Roque/SP & + \\
\hline $24 / 90$ & Bovine & Piraju/SP & + \\
\hline $265 / 91$ & Bovine & Dourados/MS & + \\
\hline $27 / 92$ & Bovine & Poços de Caldas/MG & + \\
\hline 288/99 & Equine & Guararema/SP & + \\
\hline $297 / 91$ & Bovine & Amores/MG & + \\
\hline $30 / 79$ & Caprine & Itapuí/SP & + \\
\hline $326 / 98$ & Bovine & Poços de Caldas/MG & + \\
\hline $38 / 92$ & Bubalus & Apiaí/SP & + \\
\hline $38 / 89$ & Bovine & Piraju/SP & + \\
\hline $42 / 92$ & Bovine & Cuiabá/MT & + \\
\hline $45 / 97$ & Insetivorous Bat & Ibiuna/SP & + \\
\hline $49 / 89$ & Bovine & Piraju/SP & + \\
\hline $4 C / 94$ & Vampire Bat & Taubaté/SP & + \\
\hline $52 / 90$ & Bovine & Piraju/SP & + \\
\hline $68 / 89$ & Bovine & Piraju/SP & + \\
\hline T09/95 & Vampire Bat & Taubaté/SP & + \\
\hline $13 / 91$ & Bovine & São João da Barra/SP & + \\
\hline $186 / 00$ & Bovine & Bragança Paulista/SP & + \\
\hline 390/99 & Bovine & Poços de Caldas/MG & + \\
\hline $276 / 98$ & Vampire Bat & Taubaté/SP & + \\
\hline $328 / 98$ & Bovine & Poços de Caldas/MG & + \\
\hline $38 / 93$ & Ovine & Santos/SP & + \\
\hline $59 / 89$ & Bovine & Piraju/SP & + \\
\hline $271 / 00$ & Vampire Bat & Guarulhos/SP & + \\
\hline $552 / 99$ & Equine & Itaquaquecetuba/SP & + \\
\hline $71 / 89$ & Bovine & Piraju/SP & + \\
\hline 680/91 & Canine & Goiânia/GO & + \\
\hline $687 / 91$ & Canine & Goiânia/GO & + \\
\hline 698/91 & Canine & Goiânia/GO & + \\
\hline $44 / 89$ & Canine & São João da Boa Vista/SP & $P+$ \\
\hline $17 / 89$ & Canine & Mogi-Guaçu/SP & + \\
\hline $58 / 89$ & Feline & São João da Boa Vista/SP & $P+$ \\
\hline
\end{tabular}

$a$ : number of the sample/year of isolation; $b$ : city/state

P510, 25 pmols of primer P942, $1.5 \mathrm{mM}$ of $\mathrm{MgCl}_{2}, 1$ x PCR buffer (Gibco, BRL), 1.25 units of Taq DNA polymerase (Gibco, BRL) and ultra pure water. The amplification was performed on a MJ Research PTC-200 Thermal Cycler. The heminested amplification was performed in $5 \mu$ of primary amplification template and primers P510 and P784. The following cycling conditions for the primary amplification were adopted: initial heating at $94^{\circ} \mathrm{C} / 3 \mathrm{~min}, 35$ cycles at $94^{\circ} \mathrm{C} / 45 \mathrm{sec}, 55^{\circ} \mathrm{C} / 60 \mathrm{sec}, 72^{\circ} \mathrm{C} / 90 \mathrm{sec}$ and a final extending step at $72^{\circ} / 10 \mathrm{~min}$. The thermal cycles for the nested assay were the same, except for an amplification phase of 25 cycles. PCR products were run in $2 \%$ agarose gel electrophoresis in standard TBE and stained with ethidium bromide $0.5 \mu \mathrm{g} / \mathrm{ml}$ (Sambrook et al. 1989). Gels were observed under UV light and photographed.

Amplicons yielded by both primer pairs are shown in the Figure. The Table shows hn-PCR results in samples from several Brazilian localities positive for rabies by FAT/
MIT. The ten samples which yielded negative results by FAT/MIT also yielded negative results by PCR (results not shown). Total concordance between hn-PCR and FAT/ MIT was observed. Considering that other kind of rabies virus may be found in rural environment, 5 canine and 1 feline rabid samples were tested by the hn-PCR, yielding positive results in all cases.

Detection threshold for the hn-PCR method was evaluated using normal brain homogenates of a mouse spiked with serial ten-fold dilutions of Pasteur virus strain. Briefly, brain homogenates from experimentally RV infected mouse containing $10^{5.4} \mathrm{LD} 50 / \mathrm{ml}$ were ten-fold serially diluted with brain homogenates from a non-infected mouse. Titration of the brain homogenates from the experimentally infected mouse was performed following the method described elsewhere (Reed \& Muench 1938). Brain homogenates containing from $10^{4.4} \mathrm{LD} 50 / \mathrm{ml}$ to $10^{0.4} \mathrm{LD} 50 /$ $\mathrm{ml}$ were tested by PCR.

The performance of hn-PCR on RV-infected brain tissues at various stages of decomposition was also evaluated. Brain homogenates from a mouse experimentally inoculated with PV strain were left at room temperature for 24, 48, 72 and $96 \mathrm{~h}$, and then tested by hn-PCR. The hnPCR was able to detect $10^{4.4}, 10^{3.4}, 10^{2.4}$ and $10^{1.4} \mathrm{LD} 50 /$ $\mathrm{ml}(25000,2500,250$ and $25 \mathrm{LD} 50 / \mathrm{ml})$. In the Figure, the results of hn-PCR on $10^{3.4}, 10^{2.4}, 10^{1.4}$ and $10^{0.4} \mathrm{LD} 50 / \mathrm{ml}$ are shown. The hn-PCR was also capable of amplifying RV genetic sequences from all the decomposed brain tissue samples which have been left 24, 48, 72 and $96 \mathrm{~h}$ at room temperature.

False positive results are the main problem associated with nested-PCR due to contamination with amplified DNA from the primary reaction (Forghani \& Erdman 1995). In order to avoid false positive results, some extensive precautions should be taken: (i) each step of sample handling (RNA extraction, first and second amplification steps) should be performed in different laboratories; (ii) use of disposable gloves; (iii) analyses of no more than ten samples per reaction; (iv) inclusion of negative control for each five samples. The hn-PCR described in this paper was performed in three steps, one for cDNA synthesis and two for both amplification assays.

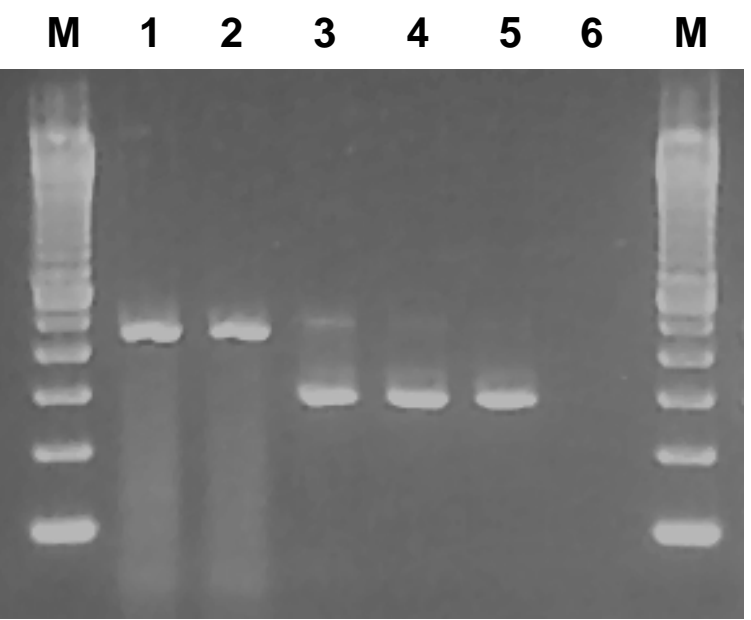

PCR products amplified from rabies virus from spiked brain homogenates. Amplicons yielded by the primer pair P510/P942 from samples spiked with Pasteur Virus strain (1 and 2); amplicons yelded by the heminested-PCR on brain homogenates spiked with $10^{3.4} \mathrm{LD}_{50} / \mathrm{ml}(3) ; 10^{2.4} \mathrm{LD}_{50} / \mathrm{ml}(4) ; 10^{1.4} \mathrm{LD}_{50} / \mathrm{ml}(5) ; 10^{0.4}$ $\mathrm{LD}_{50} / \mathrm{ml}(6) ; 100$ bp DNA ladder (M) 
As the detection of PCR products on agarose gel may reveal spurious bands sometimes (results not shown), good candidates for further improvements in the sensitivity, specificity and rapidity of the hn-PCR are the combination of reverse transcription and first amplification in a single step, and the standardization of methods other than agarose gel separation for the detection of PCR products.

At present, simultaneous use of FAT and MIT is irreplaceable for RV detection. However, their performance may occasionally be impaired in decomposed tissues and/ or samples containing no viable virus.

The goal of this study was to assess the fine performance of the primers designed for Brazilian RV isolates obtained in rural epidemiological cycle. Hn-PCR results presented here unequivocally provide an additional tool for rabies diagnosis in some special cases, such as: (i) samples which have been inadequately stored and then sent for laboratorial analysis; (ii) when FAT alone yield negative results, FAT is impracticable to perform, and results are urgent (for the entire hn-PCR procedure is accomplished in $24 \mathrm{~h}$ ); and (iii) when dealing with small amount of sample as those obtained from bats and laboratory animals in experimental studies.

\section{REFERENCES}

Black EM, McElhinney LM, Lowings JP, Smith J, Johnstone P, Heaton PR 2000. Molecular methods to distinguish between classical rabies and the rabies-related European bat lyssaviruses. J Virol Methods 87: 123-131.

Bourhy H, Tordo N, Kissi B 1993. Molecular diversity of the Lyssavirus genus. Virology 194: 70-91.

Crepin P, Audry L, Rotivel A, Gacoin C, Caroff C, Bourhy H 1998. Intravitam diagnosis of human rabies by PCR using saliva and cerebrospinal fluid. J Clin Microbiol 36: 11171121.

Forghani B, Erdmann, DD 1995. Amplification and detection of viral nucleic acids. In EH Lennette, DA Lennette, ET Lennette (eds), Diagnostic Procedures for Viral, Rickettsial and Chlamydial Infections, 7th ed., American Public Health Association, Washington, p. 97-120.

Heaton PR, Johnstone P, MCelhinney LM, Cowley R, O’Sullivan
E, Whitby JE 1997. Heminested PCR assay for detection of six genotypes of rabies and rabies-related viruses. J Clin Microbiol 35: 2762-2766.

Heaton PR, McElhinney LM, Lowings JP 1999. Detection and identification of rabies and rabies-related viruses using rapidcycle PCR. J Virol Methods 81: 63-69.

Kalmovarin N, Tirawatnpong T, Rattanasiwamoke R, Panpanich T, Hemachuda T 1993. Diagnosis of rabies by polymerase chain reaction. J Infec Dis 167: 207-210.

Kissi B, Tordo N, Bourhy H 1995. Genetic polymorphism in the rabies virus nucleoprotein gene. Virology 209: 526-537.

Meslin FX, Kaplan MM, Koprowsky H 1996. Laboratory Techniques in Rabies, 4th ed., WHO, Geneva, 476 pp.

Reed LJ, Muench H 1938. A simple method of estimating fifty per cent endpoints. Am J Hyg 27: 493-497.

Rychlik W, Rhoads RE 1989. A computer program for choosing optimal oligonucleotides for filter hybridization, sequencing and in vitro amplification of DNA. N Acid Res 17: 85438551.

Sacramento D, Bourhy H, Tordo N 1991. PCR technique as an alternative method for diagnosis and molecular epidemiology of rabies virus. Mol Cell Probes 5: 229-240.

Sambrook J, Fritsch EF, Maniatis T 1989. Molecular Cloning: a Laboratory Manual, 2nd ed., Cold Spring Harbor Laboratory Press, Cold Spring Harbor, 957 pp.

Smith JS, Orciari LA, Yager P A, Seidel HD, Warner CK 1992. Epidemiological and historical relationships among 87 rabies virus isolates as determined by limited sequence analysis. $J$ Infec Dis 166: 296-307.

Thompson JD, Gibson T J, Plewniak F, Jeanmougin F, Higgins DG 1997. The Clustal X windows interface: flexible strategies for multiple sequence alignment aided by quality tools. N Acids Res 24: 4876-4882.

Tordo N 1991. Contribution of molecular biology to vaccine development and molecular epidemiology of rabies disease. Mem Inst Butantan 53 (Supl.1): 31-51.

Whitby JE, Johnstone P, Sillero-Zubiri C 1997. Rabies virus in the decomposed brain of ethipian wolf detected by nested reverse transcription-polymerase chain reaction. J Wild Disease 33: 912-915.

Wilkinson L 1988. Understanding the nature of rabies: an historical perspective. In JB Campbell, KM Charlton (eds), Rabie, Kluwer Academic, Boston, p. 1-23. 
